\title{
Systematic review of the effects of antimicrobial cycling on bacterial resistance rates within hospital settings
}

\author{
Marianneta Chatzopoulou ${ }^{1}$ and Lucy Reynolds ${ }^{1}$ \\ ${ }^{1}$ London School of Hygiene \& Tropical Medicine
}

April 8, 2021

\begin{abstract}
Aim Antimicrobial resistance is an evolving phenomenon with alarming public health consequences. Antibiotic cycling is a widely known antimicrobial stewardship initiative which encompasses periodical shifts in empirical treatment protocols with the aim to limit selective pressures on bacterial populations. Nonetheless, mathematical models have challenged its presumable efficacy by favouring a higher heterogeneity in antibiotic administration. We present a review of the evidence regarding the actual impact of antimicrobial cycling on bacterial resistance control within hospitals. Methods A systematic literature review was conducted using the PubMed/MedLine, Embase, CINAHL Plus and Global Health databases. Results A systematic search process retrieved a sole randomised study, and so we broadened inclusion criteria to encompass quasi-experimental designs. Fifteen studies formed our dataset including seven prospective trials and eight before-and-after studies. Nine studies evaluated cycling versus a control group and produced conflicting results whilst three studies compared cycling with antibiotic mixing, with none of the strategies appearing superior. The rest evaluated resistance dynamics of each of the on-cycle antibiotics with contradictory findings. Research protocols differed in parameters such as the cycle length, the choice of antibiotics, the opportunity to de-escalate to narrow-spectrum agents and the measurement of indicators of collateral damage. This limited our ability to evaluate the replicability of findings and the overall policy effects. Conclusions Dearth of robust designs and standardised protocols limits our ability to reach safe conclusions. Nonetheless, in view of the available data we find no reason to believe that cycling should be expected to improve antibiotic resistance rates within hospitals.

Marianneta Chatzopoulou ${ }^{1}$, Lucy Reynolds ${ }^{1}$

${ }^{1}$ London School of Hygiene and Tropical Medicine, University of London, London, United Kingdom

Corresponding author: Marianneta Chatzopoulou, Papanastasiou 28, 14123, Lykovrisi, Athens, Greece, mariannetachatz@gmail.com
\end{abstract}

Running head: Antimicrobial cycling and resistance control

Keywords: Antimicrobial stewardship, antibiotic cycling, antibiotic rotation, bacterial resistance

\section{Abstract}

\section{Aim}

Antimicrobial resistance is an evolving phenomenon with alarming public health consequences. Antibiotic cycling is a widely known antimicrobial stewardship initiative which encompasses periodical shifts in empirical treatment protocols with the aim to limit selective pressures on bacterial populations. Nonetheless, mathematical models have challenged its presumable efficacy by favouring a higher heterogeneity in antibiotic administration. We present a review of the evidence regarding the actual impact of antimicrobial cycling on bacterial resistance control within hospitals.

\section{Methods}


A systematic literature review was conducted using the PubMed/MedLine, Embase, CINAHL Plus and Global Health databases.

\section{Results}

A systematic search process retrieved a sole randomised study, and so we broadened inclusion criteria to encompass quasi-experimental designs. Fifteen studies formed our dataset including seven prospective trials and eight before-and-after studies. Nine studies evaluated cycling versus a control group and produced conflicting results whilst three studies compared cycling with antibiotic mixing, with none of the strategies appearing superior. The rest evaluated resistance dynamics of each of the on-cycle antibiotics with contradictory findings. Research protocols differed in parameters such as the cycle length, the choice of antibiotics, the opportunity to de-escalate to narrow-spectrum agents and the measurement of indicators of collateral damage. This limited our ability to evaluate the replicability of findings and the overall policy effects.

\section{Conclusions}

Dearth of robust designs and standardised protocols limits our ability to reach safe conclusions. Nonetheless, in view of the available data we find no reason to believe that cycling should be expected to improve antibiotic resistance rates within hospitals.

\section{Introduction}

Evolving bacterial resistance to antimicrobial agents, one of the ten most critical public health threats according to the World Health Organization, demands immediate action[1]. Antimicrobial cycling or rotation is among the multitude of initiatives tried to streamline antibiotic prescribing, and fall within the umbrella term of antimicrobial stewardship. Cycling or rotation incurs scheduled shifts in empirical antibiotic treatment protocols, switching periodically between antimicrobial agents of similar spectrum. This practice is often adopted in high-risk settings such as Intensive Care Units and relies more or less on an intuitive perception that such scheduled rotations of antimicrobial agents could alter selective pressures on bacterial populations accordingly and thus stem the onset of resistant strains. The concept was probably further developed in the 90 's when Gerding et al reported improvements in aminoglycoside resistance rates as a result of changes in the type of predominant aminoglycoside use[2][3].

However, mathematical models have challenged the strategy's presumable effectiveness by predicting that interventions which favoured a more heterogeneous antimicrobial use would be more successful in bacterial resistance control[4][5][6]. According to a 2006 systematic literature review very few studies met inclusion criteria and lack of rigorousness in study designs for those finally included was insufficient to draw safe inferences[7] A meta-analysis following almost ten years later suggested potential benefits by the application of the particular strategy without, however, performing an in-depth evaluation of the available studies[8].

We aim to provide an updated review and evaluation of the evidence with regard to the efficacy of antimicrobial cycling on bacterial resistance control within hospital settings. Our study is a composite element of a wider project with the objective to assess the impact of different antimicrobial stewardship initiatives on bacterial resistance rates which has led to the publication of two additional papers discussing the role of antimicrobial restrictions[9] and prospective audit with feedback[10].

\section{Methods}

A systematic literature review was conducted using the PubMed/MedLine, CINAHL Plus, Global Health and Embase databases. We sought to retrieve all studies of reasonable quality which assessed the impact of antimicrobial cycling strategies on bacterial resistance within clinical settings. We also recorded antimicrobial consumption and morbidity and/or mortality rates as secondary outcomes for a more thorough assessment of the observed results.

As this study was part of a wider project we designed a broad search algorithm on the basis of definitions provided by major organizations: Infectious Diseases Society of America (IDSA), Center for Disease Preven- 
tion and Control (CDC)[11][12]. The search string covered three concepts, antimicrobial stewardship and its constituent strategies, antimicrobial resistance, and the hospital setting of the interventions:

1. (antimicrobial stewardship) OR (antibiotic stewardship) OR (audit "and" feedback) OR (restriction) OR (pre?authorization) OR (antibiotic combination*) OR (antimicrobial combination*) OR (antibiotic cycling) OR (antimicrobial cycling) OR (antibiotic rotation) OR (antimicrobial rotation) OR (antibiotic time?out*) OR (antimicrobial time?out*) OR (dose adjustment) OR (dose optimi\#ation) OR (antibiotic mixing) OR (antimicrobial mixing) OR (antibiotic de?escalation) OR (antimicrobial de? escalation) OR (parenteral oral conversion) OR (intravenous oral conversion) OR (procalcitonin) OR (electronic alert*) OR (electronic system*) OR (computeri\#ed alert*) OR (computeri\#ed system*) OR (automat* stop order*)

2. Exp Drug Utilization

3. 1 OR 2

4. (antibiotic resistan*) OR (antimicrobial resistan*) OR (multi?drug resistan*) OR (bacterial resistan*) OR (bacterial susceptib*) OR (susceptib* phenotype*) OR (antibiotic susceptib*) OR (antimicrobial susceptib*)

5. 3 AND 4

6. (nosocomial OR hospital* OR in?patient OR intensive care OR ICU*)

7. 5 AND 6

8,922 papers covering the period to 1st April 2020 were screened for relevance. Randomised studies were scarce and for this reason we decided to broaden inclusion criteria by considering quasi-experimental designs. However, we excluded simple before-and-after studies which examined cohorts lasting less than one year, to minimise confounding due to seasonality and to facilitate comparability of results. We also excluded studies which combined changes in infection control practices or applied multidisciplinary interventions due to confounding and constraints on comparability. Studies which lacked historical or parallel cohorts for comparison were not included as interpretation is impossible without some kind of internal control or comparator. Data provided by grey literature such as congress papers and reports from governmental and non-governmental organizations were outside our scope due to lack of peer review. Finally, studies which did not apply suitable statistical methods to evaluate the significance of the reported results were also excluded.

A main distinction from prior meta-research on the topic is the fact that we considered changes in infection control as well as the application of additional antimicrobial stewardship interventions as important confounding factors which should not be overlooked; this led to the exclusion of several papers which other reviews have included.

\section{Results}

Study selection turned out to be challenging. This was partly due to the characteristics of the intervention studied which preclude blinding and limit options for even partial randomization. The search process retrieved a sole cluster randomised trial and for this reason we decided to include less robust study types and perform a sensitivity analysis in case of conflicting results.

Fifteen relevant studies formed our dataset including seven prospective trials and eight simple beforeand-after studies (Table 1). Nine studies evaluated the effects of antibiotic cycling versus a control group[13][14][15][16][17][18][19][20][21]. Three papers compared antimicrobial cycling with antibiotic mixing[22][23][24], that is administering the scheduled antimicrobial agents on a successive patient basis. The last three assessed the resistance potential of each of the alternating on-cycle antibiotics, that is the variations in risk of antibiotic resistant infection and/or colonization during cycles of different predominant antibiotic use[25][26][27].

Fixed durations of each cycle ranged from one week to eight months. The rotating agents were piperacillintazobactam with cefepime in two cases[13][25], fluoroquinolones with beta lactams in three cases[18][26][27]. The rest rotated the aforementioned agents with carbapenems and aminoglycosides in varying combinations. In some protocols de-escalation to suitable narrow-spectrum agents was permitted but in others it was not, 
with six teams proceeding to de-escalation in view of bacterial susceptibility results[16][17][19][23][24][27], five teams avoiding de-escalation to increase the on-cycle antimicrobial use[14][15][18][21][26] and four teams not clarifying their practices enough for their readers to be able to ascertain specifically what they $\operatorname{did}[13][20][22][25]$. Four studies provided bacterial typing data to assist in the evaluation of cross-transmission dynamics[14][18][25][27]. Furthermore, methodologies differed as to whether surveillance cultures or cultures from clinically presumed infections, unit-wide or patient-specific, were recorded as indicators of resistance incidence.

Among those studies which compared an experimental with a control cohort there were seven simple beforeand-after and two prospective trials. Seven of these provided data with regard to antimicrobial protocols in the control group[14][15][16][18][19][20][21] and two did not set out their standard practice[13][17]. Oddly, many studies fail to state any explicit goal of their chosen intervention, but the available information suggests that the institution of an antimicrobial rotation policy aimed to increase heterogeneity of antimicrobial administration in the intervention group by utilising more antimicrobial classes of similar spectrum in a scheduled fashion. The results, however, appear rather conflicting.

In particular, if one takes into account bacterial susceptibilities to the rotated agents which are apparently a more straightforward indicator of the policy's effectiveness four studies did not achieve any measurable success and five reported variable improvement (Table 1). The most noteworthy study in the group reporting negative findings is probably the trial conducted by Toltzis et al. Its main distinctive feature is the use of a contemporary control group, and its use of bacterial typing data facilitates interpretation of the available findings. The researchers observed no benefits even when only clonally discordant isolates were taken into account[14].

The group reporting positive findings encompassed two studies which observed an increase in $P$. aeruginosa susceptibility to one and two of the rotated agents respectively[17][18] and two studies which reported improvements in Extended-spectrum Beta Lactamase (ESBL) incidence $(\mathrm{p}<0.05)$ [20][21]. One of the latter used a rather small sample while none of the aforementioned seemingly successful studies utilized bacterial typing. Thus, the possibility that the observed findings could be a result of horizontal transfer of bacterial clones due to breaks in infection control cannot be excluded as in the study conducted by Toltzis et al.

Nijssen et al reported lower colonization rates for ciprofloxacin-resistant isolates in the intervention group but no changes for cephalosporin-resistant isolates[18]. Highly homogeneous prescription of fluoroquinolones in the control arm, a radical reduction in ciprofloxacin administration in the intervention arm along with the main mechanism of fluoroquinolone resistance which incurs spontaneous chromosomal mutations favoured by increased selective pressures could perhaps explain the observed results, but no firm interpretation is possible.

Frequency of cycling did not appear to be associated with the possibility of positive or inconclusive outcomes as it varied widely in both groups. Furthermore, the fact that universal lack of randomization and blinding would potentially predispose to some degree of selection and information bias in favour of more positive outcomes, and while no specific biases were evident, this inevitable contextual bias should be taken into account.

Three studies assessed antimicrobial rotation compared to administering the agents on a successive patient basis to maximise antibiotic heterogeneity, a practice known as antibiotic mixing. Two of those, including one using the robust cluster-randomised cross-over design, observed no significant differences[23][24]. Jayashree et al reported lower resistance rates in both cycling and mixing periods compared to a three-month baseline period. The latter, however, was too short to be informative[24]. The third reported higher cefepime susceptibility rates for $P$. aeruginosa during cycling $(\mathrm{p}=0.01)$ but no further improvements[22]. De-escalation as well as combination therapy were permitted in two instances[23][24], and their allowability was not clarified in the third[22]. None of the teams used typing data to assess cross-transmission dynamics.

As for the remaining studies, Ginn et al cycled piperacillin-tazobactam with cefepime and found that cefepime showed as a more important driver for the onset of bacterial resistance with the proportion of ad- 
missions complicated by resistant infections during cefepime cycles being more than twice as high compared to piperacillin-tazobactam cycles $(\mathrm{p}<0.001)[25]$. Van Loon et al cycled levofloxacin with cefpirome and piperacillin-tazobactam. concluding that levofloxacin use was associated with higher levofloxacin-resistance rates, but cefpirome was seemingly not prone to the selection of cefpirome-resistant strains[26]. Tsukayama et al rotated fluoroquinolones with piperacillin-tazobactam but did not find any significant correlations between the on-cycle antibiotic class and the probability of resistance onset. However, the authors report high use of off-cycle antibiotics which could potentially act as a confounding factor[27].

Finally, all but two studies provided some data regarding the on- and off-cycle antimicrobial consumption during the experimental period, while seven studies measured variable side effects as indicators of the policy's potential collateral damage including morbidity and/or mortality rates reported by six studies[15][16][19][22][23][24]. None of these recorded worrying trends in intervention groups.

\section{Discussion}

Bacterial resistance to antimicrobial agents is an incessantly evolving phenomenon which threatens one of the greatest achievements of medical science, the effective treatment of infectious diseases. Overprescribing and suboptimal selection of antimicrobial agents are believed to have contributed to the acceleration of the selection of resistant strains. Thus antimicrobial stewardship has provoked the interest of the medical community as a multifaceted set of interventions which aim to optimise antimicrobial use and thus stem the onset of resistant bacterial strains.

Despite, however, the public health importance of this issue, there is a notable lack of standardised highquality research on the field to provide definite answers as to which, if any, initiatives are effective or not. We have already examined antimicrobial restrictions and audit with feedback in two papers that were recently published[9][10.] The absence of randomised models and the great heterogeneity in study protocols limited the ability to draw any firm conclusions on the aspects researched. It highlights the need for future highquality, reproducible research. Standardisation in study design would increase the utility of clinical research in this field, as meta-synthesis of studies would be possible, providing greater statistical power to detect and map the effects of intervening to try to reduce resistance, and guide clinicians.

Examination of the available literature on the potential efficacy of antimicrobial cycling gives an overall impression of rather limited success. Research papers could be roughly divided to those which evaluated cycling versus a control group and produced conflicting results and those that compared cycling with mixing with none of the strategies appearing superior to the other. Lack of success becomes more evident if one takes into account the most rigorous studies conducted by Toltzis et al[14] as well as Van Duijn et al[23 ]both of which failed to record any favourable results comparing cycling with a control group and a mixing group respectively.

Fair interpretation of the relevant data must take into account some core limitations which could influence results in either way. One such limitation is the lack of standardization of antibiotic protocols across intervention and control groups of different studies, though a general tendency to increase heterogeneity of antibiotic administration in the experimental arms was observable. It is rational to assume that the relevant baseline practices would influence whether significant changes in antibiotic resistance patterns would be recorded post-intervention. A pertinent paradigm is probably provided by Nijssen et al who compared antibiotic rotation with a control group receiving fluoroquinolones in a highly homogeneous manner. Fluoroquinolone resistance rates were decreased in the rotation arm, a trend not seen for cephalosporins. It is well-known that the main mechanism of fluoroquinolone resistance comprises point mutations in chromosomal DNA which are obviously particularly prone to selective pressures. Radical reduction in fluoroquinolone administration along with the main relevant mechanism of resistance could provide a likely explanation for the observed results further supported in the clinical literature after the application of restrictive fluoroquinolone strategies [9].

We cannot exclude the possibility that the potential of success could be pathogen-specific and depending on the monitoring protocol it could be potentially missed; a pathogen-specific effect has indeed been suggested 
by researchers in the past[8]. It is true that the majority of the available positive findings in our dataset relate to $P$. aeruginosa although we are not aware of any pathophysiological mechanism that would account for such a theory.

Failure of antibiotic cycling to produce clear benefits is consistent with the theoretical predictions generated by many mathematical models that challenge its intuitively presumed efficacy. On the basis of the aforementioned models, though, one would expect that antibiotic mixing would be more effective via maximising heterogeneous antimicrobial use. Neither assumption was confirmed in practice. Although there is high variability in research protocols and the overall quality of our data is far from satisfying to reach definite conclusions, we should bear in mind that the evolution of bacterial resistance is a complex process and the strategies tested may rely on an oversimplified model of how it may be manipulated. It is worth mentioning that antimicrobial agents of similar spectrum may possess totally different mechanisms of action, and thus may affect bacteria in different ways. In addition, infection control is a hard to standardise parameter which could influence relevant studies drastically.

At this point, it would be useful to discuss the third set of studies included in our review. The latter evaluated resistance dynamics of each of the on-cycle antibiotics during the application of antimicrobial cycling protocols. They provide little information as to the overall efficacy of cycling but could offer some ground for future research as to which agents are actually less prone to the selection of resistant strains. Ginn et al compared periods of predominant cefepime and piperacillin-tazobactam use and found that cefepime, a fourth-generation cephalosporin, was associated with higher overall resistance rates (including co- and cross-resistance). There is plenty of observational research which supports the notion that piperacillintazobactam is a less important driver of antibiotic resistance than broad-spectrum cephalosporins[9]. A rational explanation could lie on the fact that broad-spectrum cephalosporins are less effective than inhibitorbased beta-lactams in vitro against ESBLs, which are the among most widespread multidrug-resistant strains within nosocomial environments and could be theoretically preferentially selected under the pressure of inappropriate antibiotic treatment.

On the other hand, Van Loon et al concluded that the homogeneous use of cefpirome, another fourthgeneration cephalosporin, was not associated with an increase in the incidence of cefpirome-resistant strains, while both piperacillin-tazobactam and levofloxacin use provoked resistance. The results of those studies are seemingly contradictory and could be confounded either by seasonality or breaks in infection control. Such discrepancies underline the importance of the use of contemporaneous controls as well as the need for bacterial typing data in future research to facilitate a more meaningful interpretation of the data. Bacterial typing becomes especially important in view of the fact that most studies to date have used the unitwide incidence of resistant strains as the primary outcome indicator, but this is easily affected by changes in colonization pressure and/or breaks in infection control. An idea for future research would also be to differentiate colonization rates in patient groups within the same ward who have and have not participated in study protocols and use additional wards with similar baseline characteristics as comparison units.

Lack of standardization of research protocols was once again a crucial issue which limited our ability to evaluate with confidence the replicability of findings and reach safer conclusions. Research protocols differed in terms of the cycle length, the choice of empirical agents, the opportunity to de-escalate, the acquisition of typing data to assess cross-transmission dynamics, and the measurement of indicators of potential collateral damage induced by the established policies. Among the studies of our dataset it was only Van Duijn et al in 2018 who utilised a cluster-randomised cross-over design to compare cycling with mixing, which was a stronger study design than most. A more thorough evaluation would be possible only if the study included control groups and/or baseline data as well as bacterial typing to assess bacterial clonality. It is true that the conduct of research well-designed and rigorous to be of practical use to clinicians requires specialist expertise of multiple kinds, and is logistically difficult. Nevertheless, it is a worthwhile investment which should be co-ordinated by national or international public health agencies with the ultimate aim to safeguard the future value of antimicrobial agents.

\section{Conclusion}


Although we cannot exclude the possibility that yet unexplored cycling protocols could show benefits in the future we believe that the routine use of the currently tested options in current clinical practice should not be expected to improve bacterial resistance rates to any appreciable extent. We hope that this review will inspire a more standardised and rigorous approach in the future, as with some upgrading, this type of research could create an enormous contribution to the control of pathogenic bacteria worldwide.

\section{Acknowledgements and funding}

This research did not receive any specific grant from funding agencies in the public, commercial or not-forprofit sectors. The authors have no conflict of interest.

\section{References}

1. Ten threats to global health in 2019. https://www.who.int/vietnam/news/feature-stories/detail/tenthreats-to-global-health-in-2019. Accessed February 14, 2021.

2. Gerding DN, Larson TA. Aminoglycoside resistance in gram-negative bacilli during increased amikacin use. Comparison of experience in 14 United States hospitals with experience in the Minneapolis Veterans Administration Medical Center. Am J Med . 1985;79(1 SUPPL. 1):1-7. doi:10.1016/0002-9343(85)90184-6

3. Gerding DN, Larson TA, Hughes RA, Weiler M, Shanholtzer C, Peterson LR. Aminoglycoside resistance and aminoglycoside usage: ten years of experience in one hospital. Antimicrob Agents Chemother . 1991;35(7):1284-1290. http://www.ncbi.nlm.nih.gov/pubmed/1929283. Accessed March 15, 2017.

4. Bonhoeffer S, Lipsitch M, Levin BR, et al. Evaluating treatment protocols to prevent antibiotic resistance. Proc Natl Acad Sci U S A . 1997;94(22):12106-12111. doi:10.1073/PNAS.94.22.12106

5. Bergstrom CT, Lo M, Lipsitch M. Ecological theory suggests that antimicrobial cycling will not reduce antimicrobial resistance in hospitals. Proc Natl Acad Sci U S A . 2004;101(36):13285-13290. doi:10.1073/pnas.0402298101

6. Levin BR, Bonten MJM. Cycling antibiotics may not be good for your health. Proc Natl Acad Sci U S A . 2004;101(36):13101-13102. doi:10.1073/pnas.0404970101

7. Brown EM, Nathwani D. Antibiotic cycling or rotation: a systematic review of the evidence of efficacy. $J$ Antimicrob Chemother . 2004;55(1):6-9. doi:10.1093/jac/dkh482

8. Abel zur Wiesch P, Kouyos R, Abel S, Viechtbauer W, Bonhoeffer S. Cycling Empirical Antibiotic Therapy in Hospitals: Meta-Analysis and Models. PLoS Pathog . 2014;10(6). doi:10.1371/journal.ppat.1004225

9. Chatzopoulou M, Reynolds L. Role of Antimicrobial Restrictions in Bacterial Resistance Control: A Systematic Literature Review. J Hosp Infect . September 2019. doi:10.1016/J.JHIN.2019.09.011

10. Chatzopoulou M, Kyriakaki A, Reynolds L. Review of antimicrobial resistance control strategies: low impact of prospective audit with feedback on bacterial antibiotic resistance within hospital settings. Infect Dis (Auckl) . December 2020:1-10. doi:10.1080/23744235.2020.1846777

11. Dellit TH, Owens RC, McGowan JE, et al. Infectious Diseases Society of America and the Society for Healthcare Epidemiology of America Guidelines for Developing an Institutional Program to Enhance Antimicrobial Stewardship. Clin Infect Dis . 2007;44(2):159-177. doi:10.1086/510393

12. Center for Disease Prevention and Control. Core Elements of Hospital Antibiotic Stewardship Programs | Get Smart for Healthcare | CDC. http://www.cdc.gov/getsmart/healthcare/implementation/coreelements.html.

13. Cadena J, Taboada CA, Burgess DS, et al. Antibiotic cycling to decrease bacterial antibiotic resistance: a 5-year experience on a bone marrow transplant unit. Bone Marrow Transplant . 2007;40(2):151-155. doi:10.1038/sj.bmt.1705704 
14. Toltzis P, Dul MJ, Hoyen C, et al. The Effect of Antibiotic Rotation on Colonization With Antibiotic-Resistant Bacilli in a Neonatal Intensive Care Unit. Pediatrics . 2002;110(4):707-711. doi:10.1542/peds.110.4.707

15. Raineri E, Crema L, Dal Zoppo S, et al. Rotation of antimicrobial therapy in the intensive care unit: impact on incidence of ventilator-associated pneumonia caused by antibiotic-resistant Gram-negative bacteria. Eur J Clin Microbiol Infect Dis . 2010;29(8):1015-1024. doi:10.1007/s10096-010-0964-5

16. Cumpston A, Craig M, Hamadani M, Abraham J, Hobbs GR, Sarwari AR. Extended follow-up of an antibiotic cycling program for the management of febrile neutropenia in a hematologic malignancy and hematopoietic cell transplantation unit. Transpl Infect Dis . 2013;15(2):142-149. doi:10.1111/tid.12035

17. Bennett KM, Scarborough JE, Sharpe M, et al. Implementation of antibiotic rotation protocol improves antibiotic susceptibility profile in a surgical intensive care unit. J Trauma - Inj Infect Crit Care . 2007;63(2):307-311. doi:10.1097/TA.0b013e318120595e

18. Nijssen S, Fluit A, Van De Vijver D, Top J, Willems R, Bonten MJM. Effects of reducing beta-lactam antibiotic pressure on intestinal colonization of antibiotic-resistant gram-negative bacteria.Intensive Care Med . 2010;36(3):512-519. doi:10.1007/s00134-009-1714-y

19. Smith RL, Evans HL, Chong TW, et al. Reduction in rates of methicillin-resistant Staphylococcus aureus infection after introduction of quarterly linezolid-vancomycin cycling in a surgical intensive care unit. Surg Infect (Larchmt) . 2008;9(4):423-431. doi:10.1089/sur.2007.024

20. Chong Y, Shimoda S, Yakushiji H, et al. Antibiotic Rotation for Febrile Neutropenic Patients with Hematological Malignancies: Clinical Significance of Antibiotic Heterogeneity. PLoS One . 2013;8(1). doi:10.1371/journal.pone.0054190

21. Teranishi H, Koga Y, Nishio H, et al. Clinical efficacy of cycling empirical antibiotic therapy for febrile neutropenia in pediatric cancer patients. $J$ Infect Chemother . 2017;23(7):463-467. doi:10.1016/j.jiac.2017.03.020

22. Martínez J-A, Nicolás J-M, Marco F, et al. Comparison of antimicrobial cycling and mixing strategies in two medical intensive care units. Crit Care Med . 2006;34(2):329-336. http://www.ncbi.nlm.nih.gov/pubmed/16424711. Accessed March 14, 2017.

23. van Duijn PJ, Verbrugghe W, Jorens PG, et al. The effects of antibiotic cycling and mixing on antibiotic resistance in intensive care units: a cluster-randomised crossover trial. Lancet Infect Dis . 2018;18(4):401-409. doi:10.1016/S1473-3099(18)30056-2

24. Jayashree M, Singhi S, Ray P, Gautam V, Ratol S, Bharti S. Longitudinal comparative trial of antibiotic cycling and mixing on emergence of gram negative bacterial resistance in a pediatric medical intensive care unit. J Crit Care . 2020;56:243-248. doi:10.1016/j.jcrc.2020.01.013

25. Ginn AN, Wiklendt AM, Gidding HF, et al. The ecology of antibiotic use in the ICU: homogeneous prescribing of cefepime but not tazocin selects for antibiotic resistant infection. PLoS One . 2012;7(6):e38719. doi:10.1371/journal.pone.0038719

26. van Loon HJ, Vriens MR, Fluit AC, et al. Antibiotic Rotation and Development of Gram-Negative Antibiotic Resistance. Am J Respir Crit Care Med . 2005;171(5):480-487. doi:10.1164/rccm.200401-070OC

27. Tsukayama DT, Loon HJ va., Cartwright C, et al. The evolution of Pseudomonas aeruginosa during antibiotic rotation in a medical intensive care unit: the RADAR-trial. Int $J$ Antimicrob Agents . 2004;24(4):339345. doi:10.1016/j.ijantimicag.2004.04.011

Figure 1: PRISMA chart depicting the study selection process

Table 1: Catalogue of the studies assessing the effects of antimicrobial cycling on bacterial resistance rates; A p value $<0.05$ was regarded as the statistical threshold of significance in all studies and is accordingly 
recorded as such.

\begin{tabular}{|c|c|c|c|c|c|}
\hline Authors & $\begin{array}{l}\text { Study } \\
\text { Design }\end{array}$ & Setting & Protocol & Outcomes & Indicator \\
\hline $\begin{array}{l}\text { Toltzis P et al } \\
2002\end{array}$ & Controlled trial & Neonatal ICU & $\begin{array}{l}\text { Monthly cycling } \\
\text { of gentamicin, } \\
\text { piperacillin- } \\
\text { tazobactam and } \\
\text { ceftazidime for } \\
\text { suspected } \\
\text { infections due to } \\
\text { Gram-negative } \\
\text { pathogens versus } \\
\text { standard } \\
\text { practice in the } \\
\text { control group } \\
\text { (usually } \\
\text { ampicillin and } \\
\text { gentamicin for } \\
\text { suspected } \\
\text { infection at } \\
\text { birth, } \\
\text { vancomycin and } \\
\text { gentamicin for } \\
\text { hospital-acquired } \\
\text { infection, } \\
\text { ampicillin and } \\
\text { cefotaxime for } \\
\text { meningitis, and } \\
\text { piperacillin- } \\
\text { tazobactam for } \\
\text { necrotizing } \\
\text { enterocolitis) No } \\
\text { de-escalation } \\
\text { Typing to assess } \\
\text { clonality of } \\
\text { bacterial isolates }\end{array}$ & $\begin{array}{l}\text { PRIMARY } \\
\text { Similar incidence } \\
\text { of colonization } \\
\text { with resistant } \\
\text { bacilli to any } \\
\text { antibiotic } \\
\text { Similar incidence } \\
\text { of colonization } \\
\text { with resistant } \\
\text { bacilli to the } \\
\text { rotated } \\
\text { antibiotics (even } \\
\text { when only data } \\
\text { regarding } \\
\text { clonally } \\
\text { discordant } \\
\text { isolates were } \\
\text { considered) } \\
\text { OTHER } \\
\text { On-cycle } \\
\text { antibiotic use } \\
\text { 84.3\% for the } \\
\text { rotation team } \\
\text { Predominant use } \\
\text { of gentamicin in } \\
\text { the control team } \\
\text { Similar overall } \\
\text { antibiotic use } \\
\text { Similar length of } \\
\text { stay }\end{array}$ & $\begin{array}{l}\text { Unit-wide } \\
\text { surveillance } \\
\text { cultures }\end{array}$ \\
\hline
\end{tabular}




\begin{tabular}{|c|c|c|c|c|c|}
\hline Authors & $\begin{array}{l}\text { Study } \\
\text { Design }\end{array}$ & Setting & Protocol & Outcomes & Indicator \\
\hline $\begin{array}{l}\text { Cadena J et al } \\
2007\end{array}$ & Before-and-after & $\begin{array}{l}\text { Haematology- } \\
\text { Oncology } \\
\text { Unit }\end{array}$ & $\begin{array}{l}\text { Cycling of } \\
\text { piperacillin- } \\
\text { tazobactam and } \\
\text { cefepime for the } \\
\text { empirical } \\
\text { therapy of } \\
\text { neutropenic } \\
\text { fever every three } \\
\text { months versus } \\
\text { standard } \\
\text { practice during a } \\
\text { baseline period } \\
\text { (not further } \\
\text { clarified) } \\
\text { Potential of } \\
\text { de-escalation not } \\
\text { clarified No } \\
\text { typing of } \\
\text { bacterial isolates } \\
\text { to assess } \\
\text { clonality }\end{array}$ & $\begin{array}{l}\text { PRIMARY } \\
\text { Inconclusive } \\
\text { changes in } \\
\text { relevant } \\
\text { susceptibilities of } \\
\text { Enterobacterales } \\
\text { and } P \text {. } \\
\text { aeruginosa } \\
\text { Decrease in } \\
\text { ampicillin- } \\
\text { susceptible } \\
\text { Enterococcus } \\
\text { spp, } \\
\text { erythromycin- } \\
\text { and clindamycin- } \\
\text { susceptible } S \text {. } \\
\text { aureus } \text { OTHER } \\
\text { Increase in } \\
\text { cefepime and } \\
\text { piperacillin- } \\
\text { tazobactam } \\
\text { consumption } \\
\text { index from } 0.003 \\
\text { to } 0.88 \text { Increase } \\
\text { in cefepime use }\end{array}$ & $\begin{array}{l}\text { Unit-wide } \\
\text { clinically } \\
\text { indicated } \\
\text { cultures }\end{array}$ \\
\hline
\end{tabular}




\begin{tabular}{|c|c|c|c|c|c|}
\hline Authors & $\begin{array}{l}\text { Study } \\
\text { Design }\end{array}$ & Setting & Protocol & Outcomes & Indicator \\
\hline $\begin{array}{l}\text { Bennett KM et } \\
\text { al } 2007\end{array}$ & Before-and-after & Surgical ICU & $\begin{array}{l}\text { Cycling of } \\
\text { piperacillin- } \\
\text { tazobactam, } \\
\text { imipenem, } \\
\text { ceftazidime and } \\
\text { ciprofloxacin } \\
\text { every month for } \\
\text { the empirical } \\
\text { treatment of } \\
\text { suspected } \\
\text { Gram-negative } \\
\text { infections } \\
\text { (Ciprofloxacin } \\
\text { discarded later) } \\
\text { versus standard } \\
\text { practice during a } \\
\text { baseline period } \\
\text { (not further } \\
\text { clarified) } \\
\text { De-escalation } \\
\text { permitted No } \\
\text { typing of } \\
\text { bacterial isolates } \\
\text { to assess } \\
\text { clonality }\end{array}$ & $\begin{array}{l}\text { PRIMARY } \\
\text { Increase in } \\
\text { piperacillin- } \\
\text { tazobactam and } \\
\text { ceftazidime- } \\
\text { susceptible } P \text {. } \\
\text { aeruginosa } \\
\text { proportions; No } \\
\text { changes for the } \\
\text { Medical ICU } \\
\text { (Used as a } \\
\text { comparison unit) } \\
\text { Inconclusive } \\
\text { changes for E. } \\
\text { coli and } K . \\
\text { pneumoniae in } \\
\text { the Surgical } \\
\text { ICU; Increase in } \\
\text { piperacillin- } \\
\text { tazobactam- } \\
\text { resistant E. coli } \\
\text { proportions and } \\
\text { inconclusive } \\
\text { changes for } K \text {. } \\
\text { pneumoniae in } \\
\text { the Medical ICU } \\
\text { OTHER No } \\
\text { information } \\
\text { provided } \\
\text { regarding } \\
\text { secondary } \\
\text { outcomes }\end{array}$ & $\begin{array}{l}\text { Unit-wide } \\
\text { clinically } \\
\text { indicated } \\
\text { cultures }\end{array}$ \\
\hline $\begin{array}{l}\text { Smith R et al } \\
2008\end{array}$ & Before-and-after & Surgical ICU & $\begin{array}{l}\text { Cycling of } \\
\text { vancomycin and } \\
\text { linezolid for } \\
\text { suspected } \\
\text { Gram-positive } \\
\text { infections every } \\
\text { three months } \\
\text { versus primary } \\
\text { vancomycin use } \\
\text { during a baseline } \\
\text { period } \\
\text { De-escalation } \\
\text { permitted No } \\
\text { typing of } \\
\text { bacterial isolates } \\
\text { to assess } \\
\text { clonality }\end{array}$ & $\begin{array}{l}\text { PRIMARY } \\
\text { Decrease in } \\
\text { MRSA incidence } \\
\text { rates during } \\
\text { cycling Similar } \\
\text { VRE incidence } \\
\text { rates OTHER } \\
\text { Similar } \\
\text { percentage of } \\
\text { in-hospital } \\
\text { deaths according } \\
\text { to initial } \\
\text { empirical } \\
\text { therapy Similar } \\
\text { incidence rates of } \\
C \text {. difficile colitis }\end{array}$ & $\begin{array}{l}\text { Unit-wide } \\
\text { clinically } \\
\text { indicated } \\
\text { cultures }\end{array}$ \\
\hline
\end{tabular}




\begin{tabular}{|c|c|c|c|c|c|}
\hline Authors & $\begin{array}{l}\text { Study } \\
\text { Design }\end{array}$ & Setting & Protocol & Outcomes & Indicator \\
\hline $\begin{array}{l}\text { Nijssen S et al } \\
2009\end{array}$ & $\begin{array}{l}\text { Prospective } \\
\text { comparative } \\
\text { cross-over trial }\end{array}$ & $\begin{array}{l}2 \text { ICUs (Medical } \\
\text { ICU and } \\
\text { Neurosurgery } \\
\text { ICU) }\end{array}$ & $\begin{array}{l}\text { Weekly cycling } \\
\text { of ceftriaxone, } \\
\text { amoxicillin- } \\
\text { clavulanate and } \\
\text { levofloxacin or } \\
\text { ciprofloxacin as } \\
\text { empirical } \\
\text { treatment versus } \\
\text { the homogeneous } \\
\text { administration } \\
\text { of ciprofloxacin } \\
\text { or levofloxacin } \\
\text { No de-escalation } \\
\text { Typing of } \\
\text { isolates to } \\
\text { exclude clonal } \\
\text { outbreaks }\end{array}$ & $\begin{array}{l}\text { PRIMARY } \\
\text { Higher } \\
\text { colonization } \\
\text { rates for } \\
\text { ciprofloxacin- } \\
\text { resistant isolates } \\
\text { (including } \\
\text { ciprofloxacin- } \\
\text { resistant } \\
\text { cephalosporin- } \\
\text { resistant } \\
\text { isolates) during } \\
\text { the homogeneous } \\
\text { period Similar } \\
\text { colonization } \\
\text { rates for } \\
\text { cephalosporin- } \\
\text { resistant } \\
\text { Enterobacteri- } \\
\text { aceae OTHER } \\
\text { Similar overall } \\
\text { antibiotic use } \\
\text { Higher } \\
\text { ciprofloxacin use } \\
\text { during the } \\
\text { homogeneous } \\
\text { period Lower } \\
\text { third-generation } \\
\text { cephalosporin } \\
\text { use during the } \\
\text { homogeneous } \\
\text { period }\end{array}$ & $\begin{array}{l}\text { Unit-wide } \\
\text { surveillance } \\
\text { cultures }\end{array}$ \\
\hline
\end{tabular}




\begin{tabular}{|c|c|c|c|c|c|}
\hline Authors & $\begin{array}{l}\text { Study } \\
\text { Design }\end{array}$ & Setting & Protocol & Outcomes & Indicator \\
\hline $\begin{array}{l}\text { Raineri E et al } \\
2010\end{array}$ & Before-and-after & $2 \mathrm{ICUs}$ & $\begin{array}{l}\text { Cycling of } \\
\text { piperacillin- } \\
\text { tazobactam, } \\
\text { fluoroquinolones, } \\
\text { carbapenems, ce- } \\
\text { fepime/ceftazidime } \\
\text { every three } \\
\text { months for the } \\
\text { empirical } \\
\text { treatment of } \\
\text { VAP versus } \\
\text { standard } \\
\text { practice in a } \\
\text { baseline period } \\
\text { (most commonly } \\
\text { piperacillin- } \\
\text { tazobactam or } \\
\text { levofloxacin) No } \\
\text { de-escalation No } \\
\text { typing of } \\
\text { bacterial isolates } \\
\text { to assess } \\
\text { clonality }\end{array}$ & $\begin{array}{l}\text { PRIMARY } \\
\text { Similar incidence } \\
\text { of VAP due to } \\
\text { antibiotic- } \\
\text { resistant bacteria } \\
\text { Decrease in } \\
\text { cefepime- and } \\
\text { aminoglycoside- } \\
\text { resistant } P \text {. } \\
\text { aeruginosa } \\
\text { isolates Decrease } \\
\text { in cefazolin- } \\
\text { resistant K. } \\
\text { pneumoniae and } \\
\text { E. coli isolates } \\
\text { from No other } \\
\text { conclusive } \\
\text { changes } \\
\text { OTHER } \\
\text { On-cycle } \\
\text { antibiotic use } \\
\text { 83\% in Unit } 1 \\
\text { and } 88 \% \text { in Unit } \\
2 \text { Increase in } \\
\text { carbapenem and } \\
\text { extended- } \\
\text { spectrum } \\
\text { penicillin use } \\
\text { Decrease in } \\
\text { aminoglycoside, } \\
\text { fluoroquinolone, } \\
\text { 3GC and } 4 \mathrm{GC} \\
\text { use Similar } \\
\text { mortality rates }\end{array}$ & $\begin{array}{l}\text { Respiratory } \\
\text { cultures derived } \\
\text { from Ventilator- } \\
\text { associated } \\
\text { Pneumonia cases }\end{array}$ \\
\hline
\end{tabular}




\begin{tabular}{|c|c|c|c|c|c|}
\hline Authors & $\begin{array}{l}\text { Study } \\
\text { Design }\end{array}$ & Setting & Protocol & Outcomes & Indicator \\
\hline $\begin{array}{l}\text { Cumpston A et } \\
\text { al } 2012\end{array}$ & Before-and-after & $\begin{array}{l}\text { Blood and } \\
\text { Marrow } \\
\text { Transplantation } \\
\text { Unit }\end{array}$ & 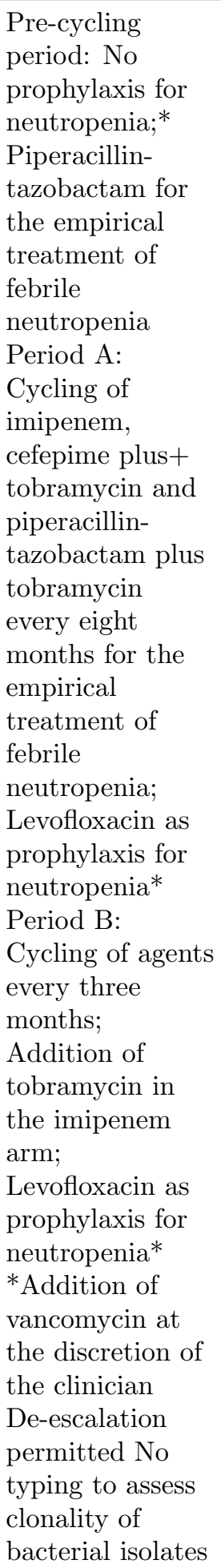 & $\begin{array}{l}\text { PRIMARY } \\
\text { Increase in } \\
\text { quinolone- } \\
\text { resistant } \\
\text { Enterobacterales } \\
\text { incidence rates } \\
\text { Increase in VRE } \\
\text { incidence rates } \\
\text { No other } \\
\text { conclusive } \\
\text { changes in } \\
\text { resistance } \\
\text { patterms } \\
\text { OTHER } \\
\text { Decrease in } \\
\text { vancomycin use } \\
\text { Similar use of } \\
\text { cefepime, } \\
\text { piperacillin- } \\
\text { tazobactam and } \\
\text { imipenem across } \\
\text { the four most } \\
\text { recent years of } \\
\text { cycling Decrease } \\
\text { in incidence rate } \\
\text { of Klebsiella and } \\
\text { E. coli } \\
\text { bacteremia and } \\
\text { candidemia } \\
\text { Similar } \\
\text { morbidity and } \\
\text { mortality } \\
\text { incidence rates }\end{array}$ & $\begin{array}{l}\text { Unit-wide blood } \\
\text { cultures }\end{array}$ \\
\hline
\end{tabular}




\begin{tabular}{|c|c|c|c|c|c|}
\hline Authors & $\begin{array}{l}\text { Study } \\
\text { Design }\end{array}$ & Setting & Protocol & Outcomes & Indicator \\
\hline $\begin{array}{l}\text { Chong Y et al } \\
2013\end{array}$ & Before-and-after & $\begin{array}{l}\text { Haematology } \\
\text { Unit }\end{array}$ & $\begin{array}{l}\text { Monthly cycling } \\
\text { of piperacillin- } \\
\text { tazobactam, } \\
\text { ciprofloxacin, } \\
\text { meropenem and } \\
\text { cefepime for the } \\
\text { empirical } \\
\text { treatment of } \\
\text { neutropenic } \\
\text { fever versus the } \\
\text { homogeneous use } \\
\text { of cefepime } \\
\text { during a baseline } \\
\text { period Potential } \\
\text { of de-escalation } \\
\text { not clarified No } \\
\text { typing of } \\
\text { bacterial isolates } \\
\text { to assess } \\
\text { clonality }\end{array}$ & $\begin{array}{l}\text { PRIMARY } \\
\text { Blood isolates: } \\
\text { Decrease in } \\
\text { cefepime- } \\
\text { resistant isolate } \\
\text { incidence from } \\
6 / 13 \text { (70\% of } \\
\text { those were } \\
\text { ESBLs) to 01/14 } \\
\text { (p=0.007); } \\
\text { Decrease in } \\
\text { ciprofloxacin- } \\
\text { resistant isolate } \\
\text { incidence Stool } \\
\text { isolates: } \\
\text { Decrease in } \\
\text { ESBL and } \\
\text { ciprofloxacin- } \\
\text { resistant E. coli } \\
\text { incidence } \\
\text { OTHER } \\
\text { Similar mortality } \\
\text { rates } 65.9 \% \\
\text { decrease in } \\
\text { unit-wide } \\
\text { cefepime-use }\end{array}$ & $\begin{array}{l}\text { Blood and stool } \\
\text { cultures from } \\
\text { patients with } \\
\text { neutropenic } \\
\text { fever }\end{array}$ \\
\hline
\end{tabular}




\begin{tabular}{|c|c|c|c|c|c|}
\hline Authors & $\begin{array}{l}\text { Study } \\
\text { Design }\end{array}$ & Setting & Protocol & Outcomes & Indicator \\
\hline $\begin{array}{l}\text { Tsukayama D et } \\
\text { al } 2004\end{array}$ & $\begin{array}{l}\text { Comparative } \\
\text { trial }\end{array}$ & $\mathrm{ICU}$ & $\begin{array}{l}\text { Cycling of } \\
\text { ciprofloxacin or } \\
\text { levofloxacin plus } \\
\text { clindamycin or } \\
\text { metronidazole } \\
\text { with piperacillin- } \\
\text { tazobactam } \\
\text { every four } \\
\text { months as } \\
\text { first-line } \\
\text { empirical } \\
\text { treatment } \\
\text { De-escalation } \\
\text { permitted } \\
\text { Typing to assess } \\
\text { clonality of } \\
\text { bacterial isolates }\end{array}$ & $\begin{array}{l}\text { PRIMARY No } \\
\text { correlation } \\
\text { between } \\
\text { particular } \\
\text { antibiotic class } \\
\text { consumption and } \\
\text { onset of } \\
\text { resistance } \\
\text { OTHER } \\
\text { Off-cycle } \\
\text { antibiotic use } \\
\text { not drastically } \\
\text { reduced }\end{array}$ & $\begin{array}{l}\text { Unit-wide } \\
\text { surveillance } \\
\text { units }\end{array}$ \\
\hline $\begin{array}{l}\text { Van Loon } \mathrm{H} \text { et } \\
\text { al } 2005\end{array}$ & $\begin{array}{l}\text { Comparative } \\
\text { trial }\end{array}$ & $\mathrm{ICU}$ & $\begin{array}{l}\text { Cycling of } \\
\text { levofloxacin plus } \\
\text { aminoglycoside } \\
\text { with beta-lactam } \\
\text { plus } \\
\text { aminoglycoside } \\
\text { (cefpirome in } \\
\text { one cycle and } \\
\text { piperacillin- } \\
\text { tazobactam in } \\
\text { the other) every } \\
\text { four months for } \\
\text { suspected } \\
\text { Gram-negative } \\
\text { infections No } \\
\text { de-escalation No } \\
\text { typing of } \\
\text { bacterial isolates } \\
\text { to assess } \\
\text { clonality }\end{array}$ & $\begin{array}{l}\text { PRIMARY } \\
\text { Colonization } \\
\text { rates for } \\
\text { Gram-negative } \\
\text { bacteria resistant } \\
\text { to levofloxacin } \\
\text { higher in periods } \\
\text { of exposure } \\
\text { Colonization } \\
\text { rates for } \\
\text { Gram-negative } \\
\text { bacteria } \\
\text { resistant to } \\
\text { cefpirome similar } \\
\text { between periods } \\
\text { of exposure and } \\
\text { non-exposure } \\
\text { Colonization } \\
\text { rates for } \\
\text { Gram-negative } \\
\text { bacteria resistant } \\
\text { to piperacillin- } \\
\text { tazobactam } \\
\text { higher in periods } \\
\text { of exposure } \\
\text { OTHER } \\
\text { On-cycle } \\
\text { antibiotic use } \\
\text { 88.5\%-100\% }\end{array}$ & $\begin{array}{l}\text { Unit-wide } \\
\text { surveillance } \\
\text { cultures }\end{array}$ \\
\hline
\end{tabular}




\begin{tabular}{|c|c|c|c|c|c|}
\hline Authors & $\begin{array}{l}\text { Study } \\
\text { Design }\end{array}$ & Setting & Protocol & Outcomes & Indicator \\
\hline $\begin{array}{l}\text { Ginn A et al } \\
2012\end{array}$ & $\begin{array}{l}\text { Comparative } \\
\text { trial }\end{array}$ & $2 \mathrm{ICUs}$ & $\begin{array}{l}\text { Cycling of } \\
\text { piperacillin- } \\
\text { tazobactam and } \\
\text { cefepime for the } \\
\text { empirical } \\
\text { therapy of sepsis } \\
\text { every four } \\
\text { months Potential } \\
\text { of de-escalation } \\
\text { not clarified } \\
\text { Typing of } \\
\text { isolates to } \\
\text { exclude clonal } \\
\text { outbreaks }\end{array}$ & $\begin{array}{l}\text { PRIMARY } \\
\text { Proportion of } \\
\text { admissions } \\
\text { complicated by } \\
\text { antibiotic- } \\
\text { resistant isolates } \\
\text { higher in } \\
\text { cefepime cycles } \\
\text { Proportion of } \\
\text { admissions } \\
\text { complicated by } \\
\text { MRSA higher in } \\
\text { cefepime cycles } \\
\text { OTHER }\end{array}$ & $\begin{array}{l}\text { Unit-wide } \\
\text { clinically } \\
\text { indicated } \\
\text { cultures }\end{array}$ \\
\hline
\end{tabular}

Similar risk of admissions complicated by any infection On-cycle antibiotic use $>60 \%$ of total use Off-cycle antibiotic use $<15 \%$ of total use 


\begin{tabular}{|c|c|c|c|c|c|}
\hline Authors & $\begin{array}{l}\text { Study } \\
\text { Design }\end{array}$ & Setting & Protocol & Outcomes & Indicator \\
\hline $\begin{array}{l}\text { Martinez J et al } \\
2006\end{array}$ & $\begin{array}{l}\text { Comparative } \\
\text { cross-over trial }\end{array}$ & $2 \mathrm{ICUs}$ & $\begin{array}{l}1^{\text {st }} \text { arm: Cycling } \\
\text { of cefepime (or } \\
\text { ceftazidime), } \\
\text { ciprofloxacin, } \\
\text { carbapenems, } \\
\text { and piperacillin- } \\
\text { tazobactam } \\
\text { every month for } \\
\text { suspected } \\
\text { Pseudomonas } \\
\text { infections } \\
2^{\text {nd arm: }} \\
\text { Successive } \\
\text { administration } \\
\text { of these agents } \\
\text { to consecutive } \\
\text { patients } \\
\text { Potential of } \\
\text { de-escalation not } \\
\text { clarified } \\
\text { Combination } \\
\text { therapy } \\
\text { permitted No } \\
\text { typing to assess } \\
\text { clonality of } \\
\text { bacterial isolates }\end{array}$ & $\begin{array}{l}\text { PRIMARY } \\
\text { Higher } \\
\text { proportion of } \\
\text { patients } \\
\text { colonised with } \\
\text { cefepime- } \\
\text { resistant } P \text {. } \\
\text { aeruginosa } \\
\text { during mixing } \\
\text { Inconclusively } \\
\text { higher } \\
\text { proportion of } \\
\text { ceftazidime and } \\
\text { carbapenem- } \\
\text { resistant } P \text {. } \\
\text { aeruginosa } \\
\text { during mixing } \\
\text { (p=. 0.06 and } \\
\text { 0.07 } \\
\text { respectively) No } \\
\text { other significant } \\
\text { differences with } \\
\text { regard to other } \\
\text { Gram-negatives } \\
\text { species OTHER } \\
\text { Higher mortality } \\
\text { rates during } \\
\text { cycling only for } \\
\text { Unit } 2 \text { Similar } \\
\text { mortality rates } \\
\text { during cycling } \\
\text { and mixing for } \\
\text { Unit } 1 \text { Higher } \\
\text { use of } \\
\text { carbapenems } \\
\text { and piperacillin- } \\
\text { tazobactam and } \\
\text { lower use of } \\
\text { cephalosporins } \\
\text { during mixing }\end{array}$ & $\begin{array}{l}\text { Unit-wide } \\
\text { surveillance } \\
\text { cultures }\end{array}$ \\
\hline
\end{tabular}




\begin{tabular}{|c|c|c|c|c|c|}
\hline Authors & $\begin{array}{l}\text { Study } \\
\text { Design }\end{array}$ & Setting & Protocol & Outcomes & Indicator \\
\hline $\begin{array}{l}\text { Van Duijn PJ et } \\
\text { al } 2018\end{array}$ & $\begin{array}{l}\text { Cluster } \\
\text { randomised } \\
\text { cross-over trial }\end{array}$ & $\begin{array}{l}\text { Multi-centre } \\
\text { ICU }\end{array}$ & $\begin{array}{l}\text { Cycling of 3GC } \\
\text { (or 4GC), } \\
\text { carbapenems } \\
\text { and piperacillin- } \\
\text { tazobactam } \\
\text { every six weeks } \\
\text { versus mixing } \\
\text { those agents } \\
\text { (administering } \\
\text { those } \\
\text { successively to } \\
\text { consecutive } \\
\text { patients) for } \\
\text { empirical } \\
\text { treatment of } \\
\text { suspected } \\
\text { Gram-negative } \\
\text { infections } \\
\text { De-escalation } \\
\text { permitted } \\
\text { Combination } \\
\text { therapy } \\
\text { permitted No } \\
\text { typing to assess } \\
\text { clonality of } \\
\text { bacterial isolates }\end{array}$ & $\begin{array}{l}\text { PRIMARY } \\
\text { Similar } \\
\text { prevalence of } \\
\text { antibiotic- } \\
\text { resistant } \\
\text { Gram-negative } \\
\text { bacteria Similar } \\
\text { incidence rate } \\
\text { ratio of } \\
\text { antibiotic- } \\
\text { resistant } \\
\text { Gram-negative } \\
\text { bacteria adjusted } \\
\text { for hand hygiene } \\
\text { compliance, } \\
\text { patient-sex and } \\
\text { proportion of } \\
\text { short-stay } \\
\text { patients Similar } \\
\text { prevalence of } \\
\text { ESBLs, } \\
\text { piperacillin- } \\
\text { tazobactam- or } \\
\text { carbapenem- } \\
\text { resistant } \\
\text { non-fermenters } \\
\text { OTHER }\end{array}$ & $\begin{array}{l}\text { Unit-wide } \\
\text { surveillance } \\
\text { cultures }\end{array}$ \\
\hline
\end{tabular}

Similar mortality rates and similar length of stay during periods of mixing and cycling Similar overall use of antibiotics and similar use of study antibiotics between study periods Three times higher use of on-cycle antibiotics compared to off-cycle use 


\begin{tabular}{|c|c|c|c|c|c|}
\hline Authors & $\begin{array}{l}\text { Study } \\
\text { Design }\end{array}$ & Setting & Protocol & Outcomes & Indicator \\
\hline $\begin{array}{l}\text { Jayashree M et } \\
\text { al } 2020\end{array}$ & $\begin{array}{l}\text { Comparative } \\
\text { trial }\end{array}$ & Paediatric ICU & $\begin{array}{l}\text { Period 1: Mixing } \\
\text { piperacillin- } \\
\text { tazobactam, } \\
\text { imipenem and } \\
\text { cefepime } \\
\text { (administering } \\
\text { those } \\
\text { successively to } \\
\text { consecutive } \\
\text { patients) for } \\
\text { suspected } \\
\text { Gram-negative } \\
\text { infections Period } \\
\text { 2: Cycling the } \\
\text { aforementioned } \\
\text { agents every } \\
\text { month } \\
\text { De-escalation } \\
\text { permitted } \\
\text { Combination } \\
\text { therapy } \\
\text { permitted No } \\
\text { typing to assess } \\
\text { clonality of } \\
\text { bacterial isolates }\end{array}$ & $\begin{array}{l}\text { PRIMARY } \\
\text { Higher } \\
\text { percentage of } \\
\text { resistant isolates } \\
\text { during baseline } \\
\text { period than in } \\
\text { mixing, cycling } \\
\text { and washout } \\
\text { periods Similar } \\
\text { percentage of } \\
\text { resistant isolates } \\
\text { during mixing } \\
\text { and cycling } \\
\text { OTHER } \\
\text { Similar mortality } \\
\text { rates between } \\
\text { periods Similar } \\
\text { episodes of } \\
\text { healthcare- } \\
\text { associated } \\
\text { infections during } \\
\text { mixing and } \\
\text { cycling but lower } \\
\text { than baseline } \\
\text { Similar overall } \\
\text { use of antibiotics } \\
\text { between all } \\
\text { phases }\end{array}$ & $\begin{array}{l}\text { Unit-wide } \\
\text { surveillance } \\
\text { cultures }\end{array}$ \\
\hline
\end{tabular}

